Original Contribution

\title{
PEROXIDASE, POL YPHENOL OXIDASE AND PROTEIN CHANGES IN OLIVES DURING ADVENTITIOUS ROOT FORMATION
}

\author{
E. Aslmoshtaghi*, A. R.Shahsavar \\ Department of Horticultural Science, College of Agriculture, Shiraz University, Shiraz, Iran
}

\begin{abstract}
Changes of peroxidase, polyphenol oxidase and protein activities were assessed during the rooting process of two cultivars of olive. Cuttings bases were submitted to a quick dip treatment to promote rooting, using indol-3-butyric acid (IBA). Samples for quantification of enzyme activities were collected at 0-60-120 days after culture. The highest peroxidase activities were measured at first of the sampling, these values decreased in connection with the root formation. Polyphenol oxidase activity maximized on the 60 days and then declined to a minimum on 120 days in both cultivars. The total protein contents increased during 60 days of culture. All these results indicate that peroxidase, polyphenol oxidase and protein are more important in rooting of olive cuttings.
\end{abstract}

Key words: cutting, enzyme activities, rooting

\section{INTRODUCTION}

Olive (Olea europaea L.) has been propagated mainly by cutting. Stem cuttings are the important means of vegetative propagation in horticultural industry for mass production within a short time $(1,2)$. However, there are great differences in the rooting potential among olive cultivars and these have been categorized into three groups, easy, moderate and hard-to-root cultivars. In olive the capacity to develop adventitious roots has proved to be extremely variable among cultivars (3). Auxins have been showed to have the greatest effect on rooting $(4,5)$. Nevertheless, auxins have failed to promote root initiation or they had only a slight rooting effect in the case of hard-to-root olive cultivars $(2,3)$. Adventitious rooting consists of three successive, but interdependent, physiological phases (induction, initiation and expression) with different requirements (6). The induction phase comprises molecular and biochemical events with no visible change. The initiation phase is characterized by cell division and root primordia organization.

*Correspondence to: E. Aslmoshtaghi,

Department of horticultural sciences, college of Agriculture, Shiraz University. Shiraz. Iran, Email: elham-aslmoshtaghi@shirazu.ac.ir
The expression phase consists of the intrastem growth of root primordia and the emergence of roots $(7,8)$. The ability to form adventitious roots is affected by genotype, stock plants, types of cuttings, collection date, and endogenous factors related to cutting $(9,10)$. Someone showed that in many species, endogenous specific rooting factors determine the rooting potential of the cultivars. These factors were found to be synthesized in the leaves and buds and translocate to the base of the cutting (11). Nevertheless, other reports have provided evidence that the difficulty in rooting olive cuttings could not be correlated with the anatomical structure of the cutting, and the genetic, biochemical or physiological causes, rather than anatomical ones, could be related to the in capacity of several olive cultivars to form adventitious roots (8). There is a close relationship between the occurrence of adventitious roots in plants and their peroxidase (POD, EC 1.11.1.7), polyphenol oxidase (PPO, EC 1.10.3.1) activities as well as their protein content (12). Peroxidases are hemcontaining enzymes that catalyze the oxidation of a diverse group of organic compounds. It has been suggested that peroxidase play significant roles in plant growth, differentiation and development, in hormone catabolism and in lignin 
polymerization (13). Peroxidases are known to be good physiological markers of rooting in many species and there is substantial evidence that peroxidase activities in plant cuttings are related in some way to rooting $(4,14)$. Polyphenol oxidase is a copper contacting enzyme localized in the thylakoids of plastids, which catalysis the oxidation of phenolic in to quinones. It is also involved in the defense mechanism of plants against environmental stresses. Furthermore, PPO plays a key role in rhizogenesis where it is involved in regulating the synthesis of phenolic precursors needed for lignin biosynthesis during root differentiation $(13,15)$. The objective of this study was to examine peroxidase, polyphenol oxidase and protein content changes during the induction, initiation phases and root development in an easy and difficultto root olive cultivars.

\section{MATERIAL AND METHODS}

Cuttings were collected from 15-year-old mother plants of two olive cultivars, the selected cultivars were 'Roghani', an easy-toroot and 'Konservalia' which is a difficult-to root one. Sub apical cuttings 7-10 cm long were cut, with four leaves. The base of each cutting was treated for $5 \mathrm{~s}$ with $4000 \mathrm{mg} \mathrm{l}^{-1} \mathrm{IBA}$ dissolved in a $45 \%$ aqueous solution of ethanol while cuttings dipped for $5 \mathrm{~s}$ in $45 \%$ aqueous solution of ethanol served as control. The cuttings were finally put under an automatic mist unit. The cuttings were misted for 20 s every $6 \mathrm{~min}$. The average air and rooting medium temperature were $29{ }^{\circ} \mathrm{C}$ and $24{ }^{\circ} \mathrm{C}$ respectively. At the end of the rooting period rooting percentage, number of roots and roots length were recorded. Samples of cuttings were taken just before planting (day 0) and at 60,120 days after planting. Sampled were frozen immediately in liquid nitrogen, lyophilized, ground and stored in deep freezer $\left(-80^{\circ} \mathrm{C}\right)$ until analysis. Each sample $(0.5 \mathrm{~g})$ from each replication at each of the three Stages of sampling in both cultivars were blended in a homogeniser containing liquid nitrogen for $1 \mathrm{~min}$, then crushed in liquid nitrogen in a mortar and homogenised in $2 \mathrm{ml}$ of extraction buffer [0.607 g Tris-base, $0.05 \mathrm{~g}$ polyvinylpyrolidone (PVP), in $50 \mathrm{ml}$ of distilled water, $\mathrm{pH}$ 8]. The homogenate was centrifuged at $13,000 \times g$ for $15 \mathrm{~min}$ at $4^{\circ} \mathrm{C}$ and the supernatant was collected and used to assay for total soluble protein concentration and the separate enzyme activities (16). Total soluble protein (TSP) concentrations were determined according to Bradford (17). Twenty $\mu 1$ of each extract was diluted with $80 \mu \mathrm{l}$ of extraction buffer, as above. Five $\mathrm{ml}$ of fresh Coomassie Brilliant Blue-G 250 reagent was then added and the mixture was stirred for 2 min. The absorbance was measured at $595 \mathrm{~nm}$, after 5 min. Bovine serum albumin was used as the standard and TSP concentrations were expressed in $\mathrm{mg} \mathrm{g}^{-1}$ fresh weight (FW). Peroxidase (POD) activity was assayed by the method of Chance and Maehly (18), using guaiacol. Guaiacol oxidation (tetraguaiacol formation) was monitored by reading the absorbance at $470 \mathrm{~nm}$ at the moment of adding the enzyme extract and $1 \mathrm{~min}$ later. The difference in absorbance $\left(\Delta \mathrm{A}_{470}\right)$ was divided by the molar extinction coefficient $\left(25.5 \mathrm{mmol}^{-}\right.$ ${ }^{1} \mathrm{~cm}^{-1}$ ) of tetraguaiacol and the specific activity of POD was expressed in mmol of $\mathrm{H}_{2} \mathrm{O}_{2} \mathrm{~min}^{-1}$ $\mathrm{mg}^{-1}$ TSP. Polyphenol oxidase activity was estimated by following the oxidation of pyrogallol at $430 \mathrm{~nm}$ and expressed as $\Delta \mathrm{A} 430$ min $\mathrm{mg}$ protein as previously described by Raymond et al. (19). The treatments were arranged in a completely randomized design with four replications of 30 cuttings each. All data were subjected to analysis of variance (ANOVA). Means were compared by the least significant difference (LSD) test at $P$ $\leq 0.05$ using SAS 9.0 software (SAS Institute, Cary, NC, USA).

\section{RESULTS AND DISCUSSION}

Olive rooting is apparently related to the genotype: in fact, the two genotypes used in this study have shown different rooting abilities. 'Roghani' exhibited the highest rooting percentage, while 'Konservalia' exhibited the lowest rooting percentage. Exogenous application IBA $4000 \mathrm{mg} \mathrm{l}^{-1}$ significantly increased cuttings percentage in the easy-to-root cv 'Roghani'. However, in the difficult-to-root cv 'Konservalia', IBA treatment was ineffective (Figure 1). The ability to form adventitious roots has been associated with the physiologic and ontogenetic age of plant material, genotype and the characteristics of the cuttings, such as growth conditions of the stock plant (9). Our results show that the application 4000 $\mathrm{mg} \quad \mathrm{l}^{-1} \mathrm{IBA}$ improved the rooting percentage in two olive cultivars in comparison with control. Cultivars also differed in the number of roots produced per cuttings; number of roots was significantly higher in cv. 'Roghani' cuttings treated with IBA at $4000 \mathrm{mg}^{-1}$ in 
comparison with control (Figure 2). IBA at $\quad 4000 \quad \mathrm{mg}^{-1}$ applied significantly increased roots length in cv. 'Roghani' in comparison with 'Konservalia' (Figure 3). The maximum number of roots in IBA treated may be due to its effect on cell wall turgidity, which accelerates cell division (4). The effectiveness of auxin to raise rooting percentage of the cuttings could be through increasing cambial activity and differentiation of root primordial or by stimulating redistribution and mobilization of some auxin cofactors towards base of the cuttings (20). Peroxidase activity decreased during 60 days after culture (Figure 4). It may be therefore be assumed that the low peroxidase activity at 60 days after culture correlated with the induction phase of adventitious root formation as proposed by Gaspar et al. (15). According to Rajeswari and Paliwak (21) the overproduction of active oxygen species (AOS) in the cell is a sign of oxidative stress and is a common phenomenon in plants, which are exposed to stressful environmental conditions. Peroxidase activity was higher in 'Konservalia' than 'Roghani' cuttings. These results are in agreement with Rajeswari and Paliwak (21) and Gaspar (15); they observed that a sharp drop in POD activity corresponds to the root induction phase, which is characterized by numerous biochemical changes and cytological and histological events. This decreasing peroxidase activity is due to the inhibition of the denova synthesis of the peroxidase iso enzymes during adventitious root formation (22). A peak of specific peroxidase activity (increase in enzyme activity followed by decrease) has generally been found in crude extracts of stem- or shoot cuttings prior to root formation $(15,23)$. POD activity has been linked to the oxidation of a wide variety of substrates including auxin (IAA). For adventitious rooting, elevated IAA concentration is required during the induction phase but during the root emergence phase, the phytohormone becomes inhibitory (13). Based on our results we can conclude that POD enzyme activities during root initiation are in close correlation with the different rooting ability of the different plant species. A clear relationship between POD activity and root initiation has been reported (24, 25). A reverse tread was observed in PPO activity. PPO activity doubled up to 60 days after culture (Figure 5). An increase in PPO activity was observed which differed significantly from the level recorded at first time in 2 cultivars. Rout (26) reported that PPO activity increased in Camellia sinensis L. cuttings during the induction and initiation phases and then decreased during the expression phase. This inverse relationship between POD and PPO activities during the initial phases of adventitious rooting was also observed by Cheniany et al. (13). Yilamz et al. (27) reported that there was a relationship between PPO activity and root formation in grape cuttings with different rooting abilities. The PPO activity showed similar patterns of change in both cultivars, but in 'konservalia' the activity changes were significantly less during 3 period of the sampling. Bhattacharya (28) proved that PPO can catalyse the metabolism of auxin, promoting the generation and development of adventitious roots. Moreover, PPO can also catalyse phenolic compounds and IAA to form "IAA-phenol complexes", which could be a type of rooting cofactor that can promote the occurrence and development of adventitious roots. Molnar and lacroix (29) found that when Hydrangea macrophylla formed adventitious roots from stem tissue, PPO activity increased dramatically when the root tip emerged. Haboguchi (30) observed the same results in carrot callus culture, when root tips emerged from callus PPO activity increased sharply. PPO activity increased significantly while a significant decrease was observed in POD activity this behavior coincided with the intense mitotic activity observed at that time, during the development of newly formed root meristems $(27,31)$. Both enzyme activities then showed the same declining trend until the end of the period of observation (120 days) corresponding to the phase of root expression. Vaughn and Duke (32) who determined that PPO plays a role in polyphenol synthesis and inhibits lignin biosynthesis, consequently affecting cell division, cell differentiation and root emergence. A perusal of the data of changes in total protein content (Figure 6) in olive cuttings with progress of root development shows that there was a slow rise of total protein contents during early phase of rooting. This trend did tally with RNA content suggesting that high protein synthesis is preceded by RNA synthesis 
ASLMOSHTAGHI E., et al.

during root development and emergence (33). A sharp rise in protein during 60 days seems to indicate that the enzymes, which are likely to participate in rooting process, are mostly synthesis during this period which are similar to the observation of Upadhyaya et al. (34).

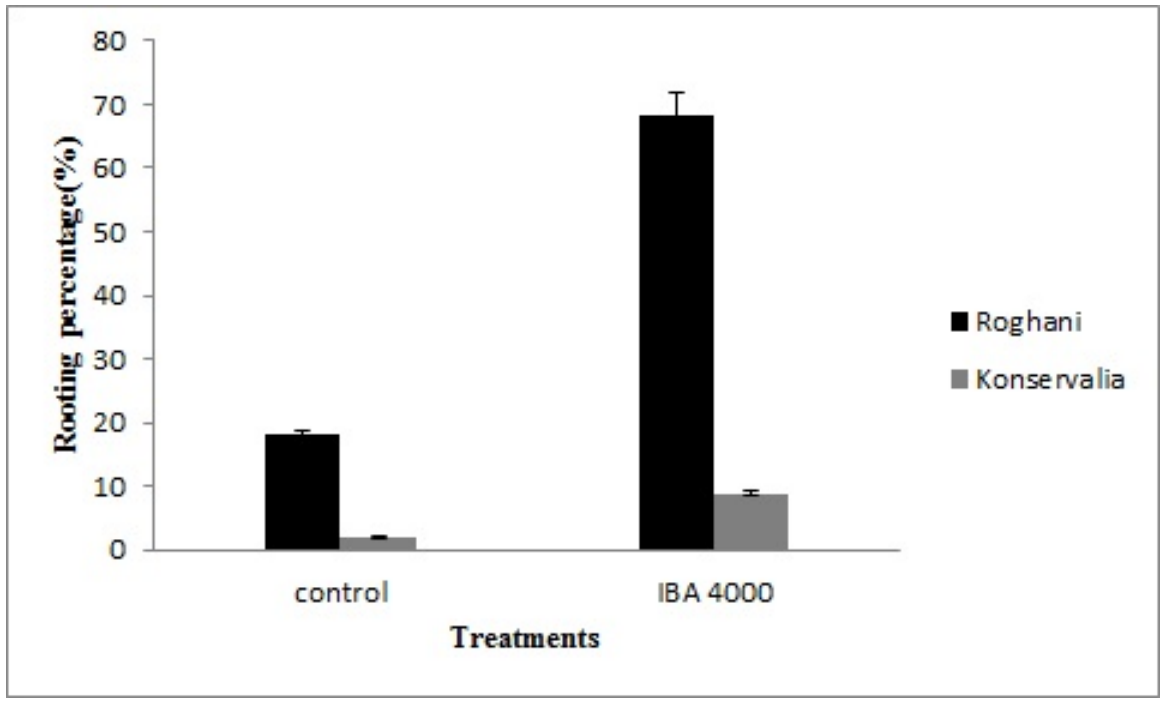

Figure 1. The effect of IBA on rooting percentage of 'Roghani 'and 'Konservalia' olive cultivars. Vertical bars are standard deviations (SD) of means.

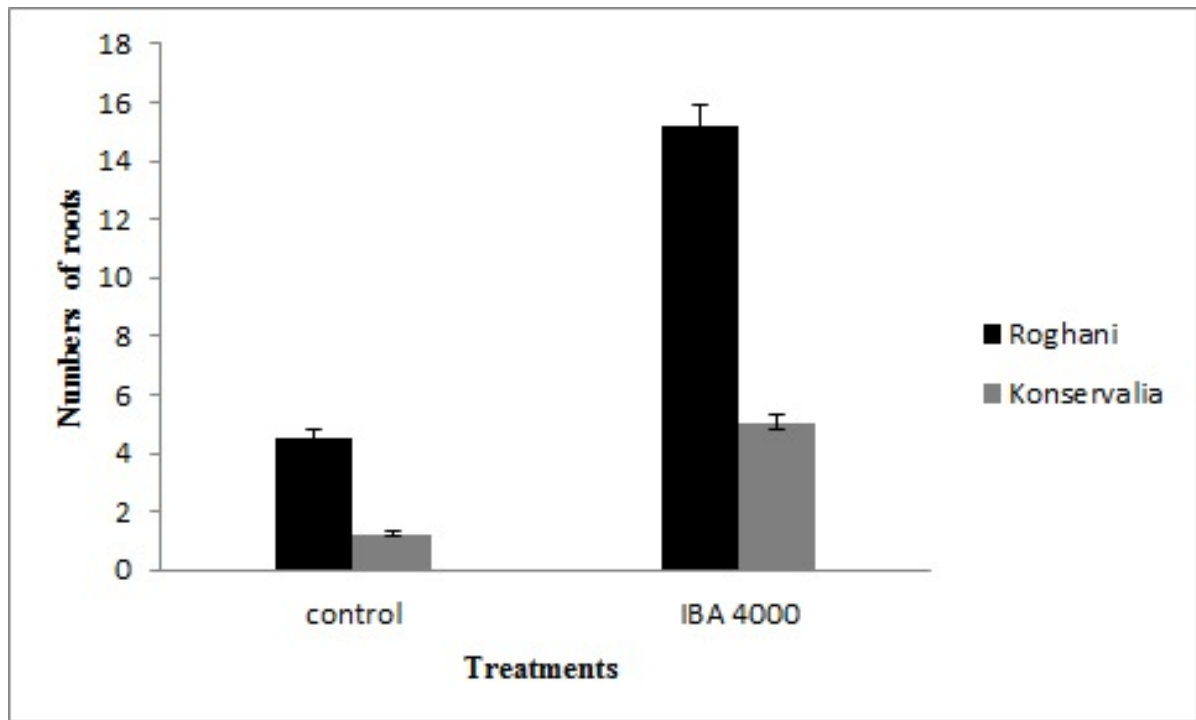

Figure 2. The effect of IBA on number of roots of 'Roghani 'and 'Konservalia' olive cultivars. Vertical bars are standard deviations (SD) of means.

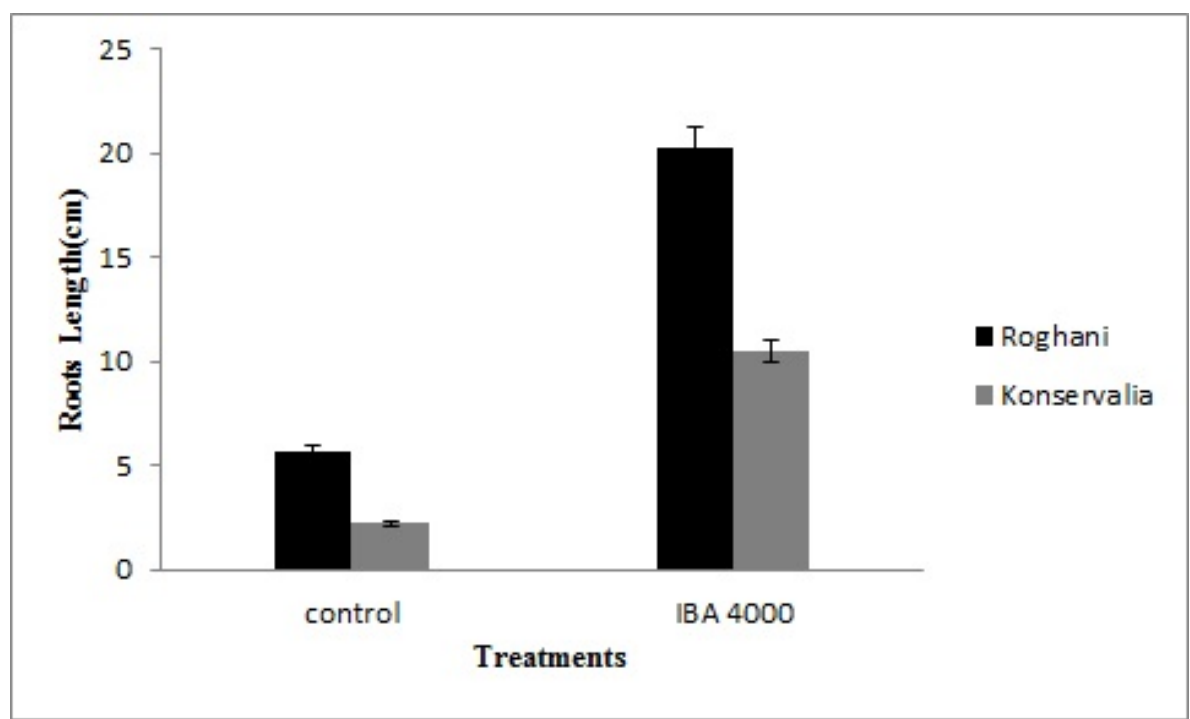

Figure 3. The effect of IBA on roots length of 'Roghani 'and 'Konservalia' olive cultivars. Vertical bars are standard deviations (SD) of means. 


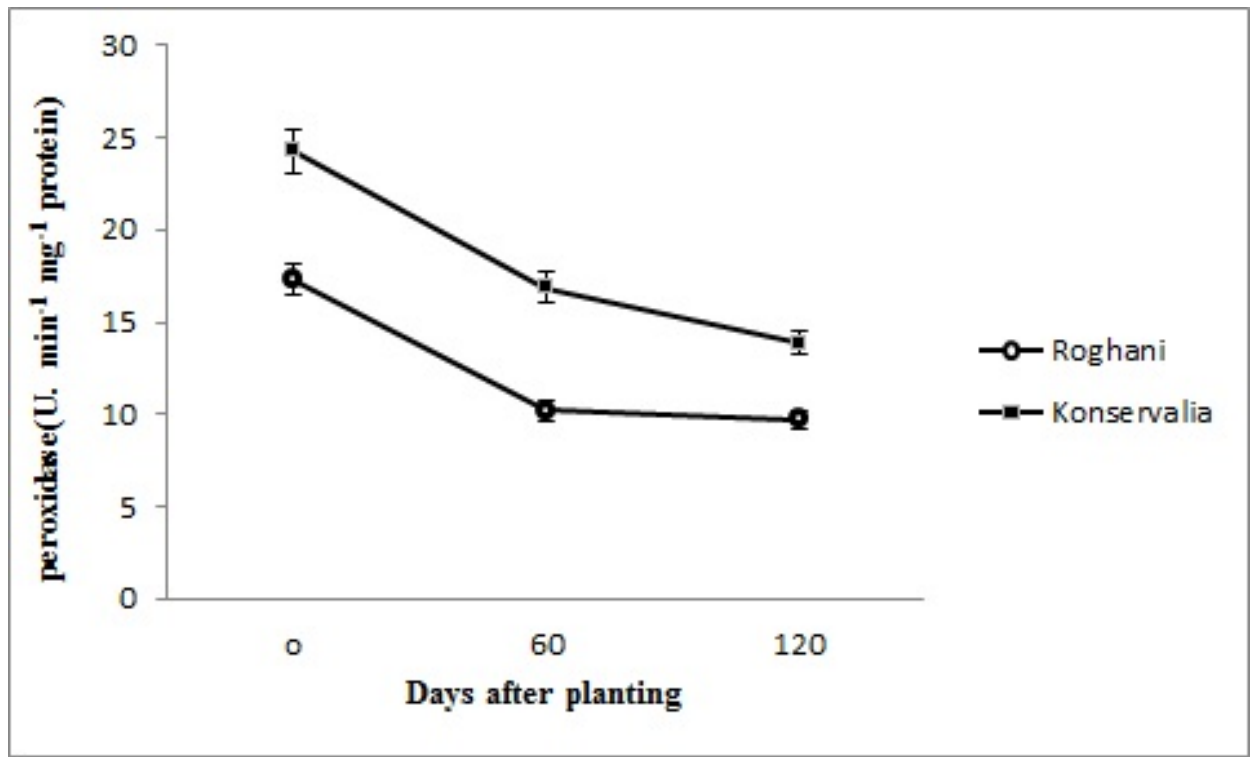

Figure 4. Changes in peroxidase activity during the rooting culture (0-120 days) of 2 olive cultivars. Vertical bars are standard deviations (SD) of means.

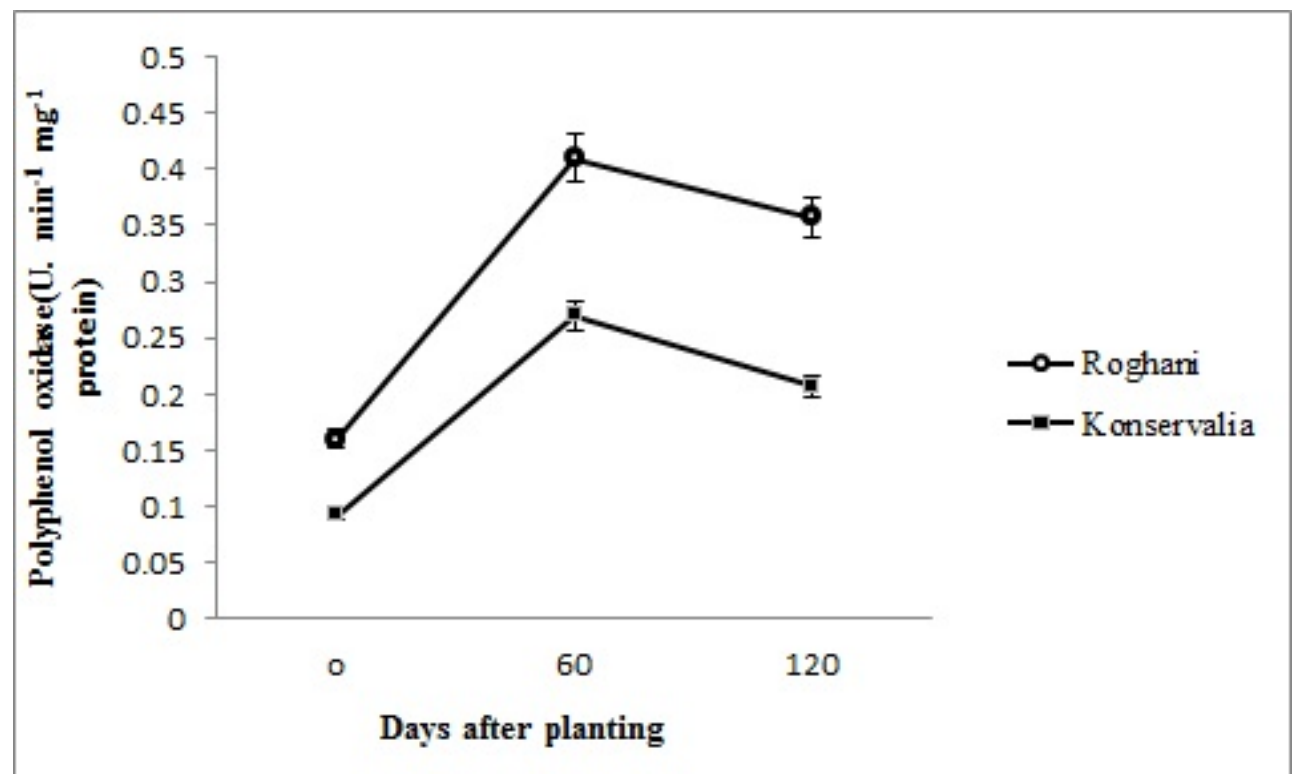

Figure 5. Changes in polyphenol oxidase activity during the rooting culture (0-120 days) of 2 olive cultivars. Vertical bars are standard deviations (SD) of means.

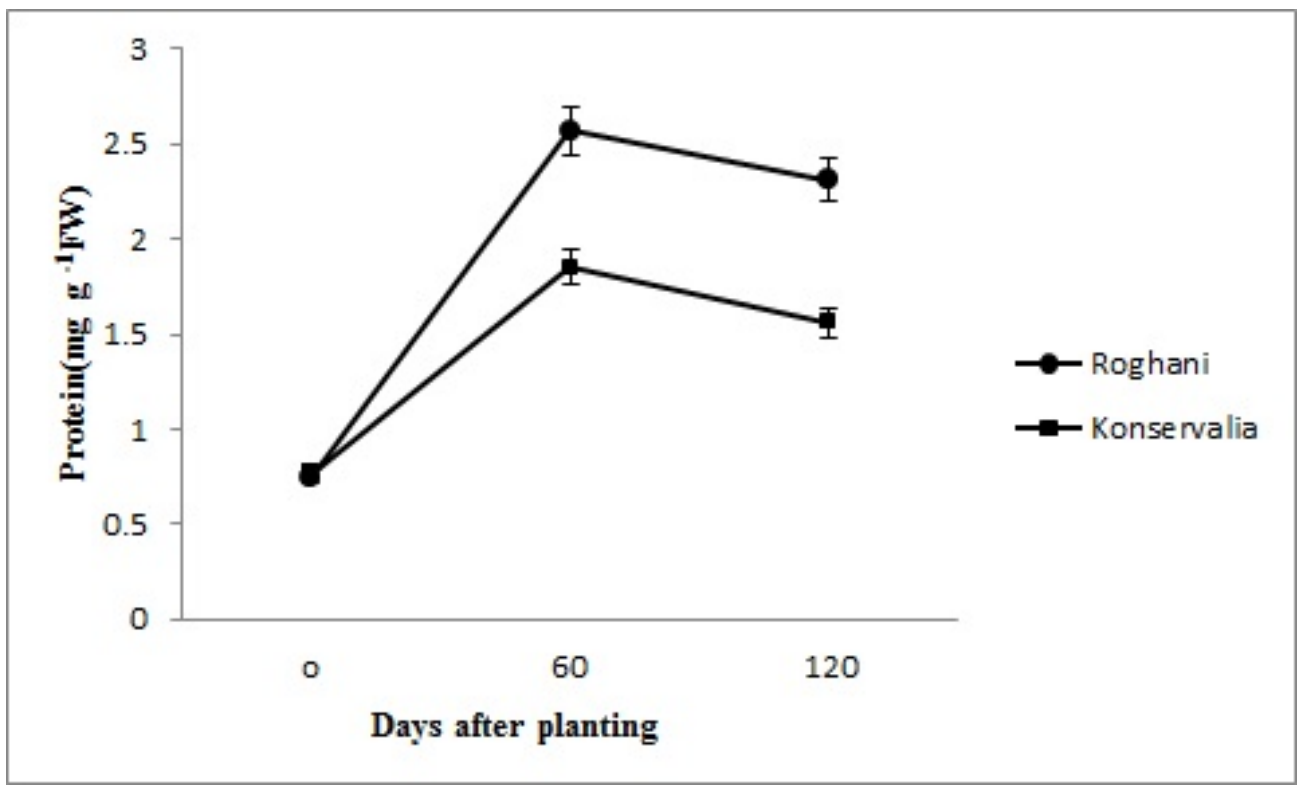

Figure 6. Changes in protein content during the rooting culture (0-120 days) of 2 olive cultivars. Vertical bars are standard deviations (SD) of means. 
ASLMOSHTAGHI E., et al.

\section{CONCLUSION}

Enzyme activities which were related to the rooting changed after cuttings culture in two olive cultivars. These changed differed over the rooting period and there were significant difference between easyto-root cv 'Roghani' and difficult-to-root cv 'Konservalia' cultivars. These changed in the activity of the POD, PPO and protein can thus be used as a marker and predictor of rooting ability in olive tree.

\section{REFERENCES}

1. Fernandes Serrano, J.M., Serrano, M.C., Amaral, E., Effect of different hormone treatments on rooting of Olea europaea cv. Galega vulgar cuttings. Acta Hort, 586: 875-877, 2002.

2. Pio, R., Costabastos, D., Berti, A.J., Rooting of different types of olive tree cutting using indol butyric acid. Ciência e Agrotecnologia Lavras, 29: 562-567, 2005.

3. Wiesman, Z., Lavee, S., Enhancement of stimulatory effects on rooting of olive cultivar stem cuttings. Sci. Hort, 62:189-192, 1995.

4. Ludwig-Muller, J., Peroxidase isoenzymes as markers for the rooting ability of easy-to root and difficult-toroot Gravillea species and cultivars of Protea obstusifolia (Proteaceae). In Vitro Cell Dev Biol Plant, 39: 377-383, 2003.

5. Negash, L., Vegetative propagation of the threatened African wild olive. New Forest, 26: 137-146, 2003.

6. Hartmann, H.T., Kester, D.E., Davies, F.T., Plant propagation: principles and practices. Prentice Hall, Inc., Englewood Cliffs, New Jersey. 1989.

7. Ford, Y.Y., Bonham, E.C., Cameron, R.W.F., Blake, P.S., Judd, H.L., Harrison-Murray, R.S., Adventitious rooting: examining the role of auxin in an easy- and a difficult-to-root plant. Plant Grow Regul, 36:149-159, 2001.

8. Sebastiani, L., Tognetti, R., Growing season and hydrogen peroxide effects on root induction and development in Olea europaea L. (cvs 'Frantoio and Gentile di Larino') cuttings. Sci. Hort, 100: 75-82, 2004.

9. Kibber, H., Johnston, M.E., William, R.R., Adventitious root formation in cuttings of Backhousia citriodora F. Muell 1. Plant genotype, juvenility and characteristics of cuttings. Sci Hort, 102: 133-143, 2004.

10.Tworkoski, T., Takeda, F., Rooting response of shoot cuttings from three peach growth habits. Sci. Hort. 115: 98-100, 2007.

11.Aslmoshtaghi, E., Shahsavar, A.R., Endogenous soluble sugars, starch contents and phenolic compounds in easy - and difficult - to - root olive cuttings. J. Biol. Environ. Sci, 4: 83-86, 2010.

12.Christensen, J., Bauw, G., Welinder, K., Montagu, M., Boerjan, W., Purification and characterization of peroxidase correlated with lignification in poplar xylem. J. Plant Physiol,118: 125-135, 1998.

13. Cheniany, M., Ebrahimzadeh, H., Nejad, A.M., Vahdati, K., Leslie, C., Effect of endogenous phenols and some antioxidant enzyme activities on rooting of Persian walnut. Afri. J. Plant Sci, 4(12):479-487, 2010.

14.Tehranifar, A., Mahmoody Tabar, S., Selahvarzi, Y., Balandary, A., Kharrazi, M., Biochemical changes in barberries during adventitious root formation: the role of indole-3-butyric acid and hydrogen peroxide. Spanish $J$. Agri. Res. 12: 477-485, 2014.

15.Gaspar, T., Kevers, C., Hausman, J.F., Berthon, J.Y., Ripetti, V., Practical uses of peroxidase activity as a predictive marker of rooting performance of micro propagation shoots. Agronomie, 12: 757-765, 1992.

16.Qaddoury, A., Amssa, M., Endogenous phenolic content, peroxidase and polyphenoloxidase activities in date palm (Phoenix dactylifera L.) offshoots related to rooting ability. Acta Physiol. Plantarum, 25:417-421, 2003.

17.Bradford, M., A rapid and sensitive method for the quantitation of microgram quantities of protein utilizing the principle of protein dye binding. Analytical Biochem, 72: 248257, 1976.

18.Chance, B., Maehly, A.C. Assay of catalase and peroxidase. Methods Enzym, 2:764$775,1955$.

19.Raymond, J., Pakariyatham, N., Azana, J.L., Purification and some properties of polyphenol oxidase from sun flower seeds. Phyto Chem, 34: 927-931, 1993.

20.Kevresan, S., Kovacevic, B., CirinNovta, V., Kuhajda, K., Kandrac, J., Pavlovic, K., Grbovic, L., Biochemical changes in cuttings of Robinia pseudoacacia after treatment with naphthenate. $J$ Serb Chem Soc, 72: 953-959, 2007. 
21.Rajeswari, V., Paliwak, K., Peroxidase and catalase during in vitro adventitious shoot organogenesis from hypocotyls of Albizia odoratissima. Acta Physiol. Plantarum. 30:825-832, 2008.

22.Chao, I.L., Cho, C.L., Chen, L.M., Liu, Z.H., Effect of indole-3-butyric acid on the endogenous indol-3-acetic acid and lignin contents in soybean hypocotyl during adventitious root formation. $J$. Plant Physiol, 158: 1257-1269, 2001.

23.Azamal, H., Changes of soluble sugars and enzymatic activities during adventitious rooting in cuttings of grewia optiva as affected by age of donor plants and auxin treatments. Amer. J. Plant Physiol, 7: 1-16. 2012.

24.Cho, H.Y., Chang, C.Y., Huang, L.C., Tsai, J.B., Liu, Z.H., Indole-3-butyric acid suppresses the activity of peroxidase while inducing adventitious roots in Cinnamomum kanehirae. Bot. Studies, 52: 153-160, 2011.

25.Hatzilazrou, S.P., Syros, T.D., Yupsanis, T.A., Bosabalidis, A.M., Economous, A.S., Peroxidase, lignin and anatomy during in vitro and $e x$ vitro rooting of gardenia (Gardenia jasminoides) micro shoot. J. Plant Physiol, 163: 827-836, 2006.

26.Rout, G.R., Effect of auxins on adventitious root development from single node cuttings of Camellia sinensis L. Kuntze and associated biochemical changes. Plant Grow. Regul, 48: 111-117, 2006.

27.Yilmaz, H., Taskin, T., Otludil, B., Polyphenol oxidase activity during rooting in cuttings of grape (Vitis

\section{ASLMOSHTAGHI E., et al.}

vinifera L.) varieties. Turkish J. Bot, 27: 495-498, 2003.

28.Bhattacharya, N.C., Enzyme activities during adventitious rooting. In: Adventitious root formation in cuttings. (Davis, T. D., Haissig B.E., Sankhla N., Eds.). Discords press, Portland. OR, USA, pp. 88-101, 1988.

29.Molnar, J.M., Lacroix, L.J., Studies of the rooting of cuttings of Hydrangea macrophylla enzyme changes. Canadian J. Bot, 50:315-322, 1972.

30.Haboguchi, K., Alternations in polyphenol oxidase activity during organ re-differentiation in carrot callus cultured in vitro. Plant Cell Physiol, 18:181-189, 1977.

31.Kaur, S., Cheema, S.S., Chabra, B.R., Talwar, K.K., Chemical induction of physiological changes during adventitious root formation and bud break in grapevine cuttings. Plant Grow Regul, 37: 63-68, 2002.

32.Vaughn, K.C., Duke, S.O., Tentoxin stops the processing of polyphenol into an active enzyme. Plant Physiol, 60: 106-112, 1984.

33.Nag, S., Paul, A., Choudhuri, M.A., Role of endogenous nucleic acid and protein in adventitious root formation in mug bean cuttings. Inter. J. Innovative Res. Sci. Engi. Technol, 5:1337-1341, 2013.

34.Upadhyaya, A., Davis, T.D., Sankhla, N., Some biochemical changes associated with paclobutrazol induced root formation on bean hypocotyl cuttings. Annals Bot, 57:309-315, 1986. 